\title{
Physico-chemical and mineral analysis of some Surface and underground waters from iron mining zone of Kogi State, Nigeria.
}

\author{
Adegbe A.A, Yahaya A. Emurotu J.E \\ Department of Chemistry, Kogi State university Anyigba, Kogi State, Nigeria.
}

\begin{abstract}
The study investigates some physicochemical properties ( $\mathrm{pH}$, conductivity, total dissolved solid alkalinity, chromium, cadmium, lead etc) of surface and underground water selected from different locations in iron mining zone of Kogi State, North Central Nigeria. The study was conducted in two seasons: rainy and dry seasons. The results of the analysis show no significant difference between the physicochemical properties in the rainy and dry season at $\alpha=0.05$ levels. The soil $p H$ was found to be weakly acidic in the dry season and weakly alkaline in the rainy season. The electrical conductivity ranges from 180.0-714.2 $\mathrm{sscm}^{-1}$ in the dry season and 181.0-718.2 $\mu \mathrm{scm}^{-1}$ in the rainy season. Total dissolved solid ranges from 70.2-207.3 $\mathrm{mgL}^{-1}$ in the dry season and 75.3-207.9 $\mathrm{mgL}^{-1}$ in rainy season and alkalinity ranges from 89.6-416.0 in the dry season and 90.6-417.1 in the rainy season. The concentrations of heavy metals determined by APLHA 4 model Atomic Absorption Spectrophotometer for both dry and rainy seasons respectively are 0.10-2.10 mgL $\mathrm{L}^{-1}$ and 0.01-1.92

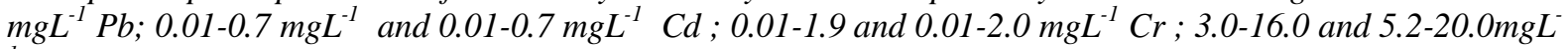
${ }^{1}$ for Fe respectively. The water bodies sampled were found to contained significant amount of toxic metals based on pollution index calculated.
\end{abstract}

Keywords: groundwater, surfacewater, heavy metals, pollution index, physicochemical

\section{Introduction}

Water like air is one of the most important natural resources of man, without which life cannot exist. Water is assessed in order to know the extent of contamination by various pollutants which are either intermittently or continuously discharged into it through several modes. Such pollutant have been identified to be deleterious to human's health and other living organism in the environment [1].Water resources have been the most exploited natural system since the world begun and it is used for both domestic, industrial and agricultural activities. The usage depends on the quality of water. Surface water (river, stream, lake and dam etc) and underground water (borehole and well etc) can serve as sources for drinking water. But with the increasing contamination of the surface water, there is now an increasing reliance on underground water for drinking and domestic purposes since it is believed to be pure through natural purification processes [2]. However, underground water can also be polluted through various ways such as seepage from effluent waters, fertilizer from agricultural activities, mining activities, vehicle maintenance and sewage disposal and domestic waste [3]. The polluting ability of those pollutants depend on their intrinsic properties determined by their structure or nonchemical factors like their production and pattern of use [4]. Some of these pollutants are untreated chemical wastes discharged from industries containing toxic substances which may react with an organ of the living system,thereby resulting into complications that cannot be easily treated by either oxidation or metabolic activities [5].Since the effects of metals in water ranges from beneficial through troublesome to dangerously toxic depending on concentration, it becomes imperative that thorough physical, chemical and biological examination be carried out to provide idea of extent of treatment needed to make the water potable [6]. Analysis of cations is often carry out by a number of methods; gravimetric colorimetry flame photometry, polarography, spectrophotometry[7,8,9] .

Many researchers have analysed light and heavy metals in sewage, sludgewater, borehole, well water and other environmental samples using different techniques[10,11]. The levels of trace metals in surface and underground water samples have been shown to cause direct or indirect symptoms of toxicity and hence the analytical control of these metals in water is of utmost importance. Therefore, the amount of these hazardous metals in surface and underground waters and their subsequent effects to human health gave rise to the significance of this study.

\section{Materials and Methods}

All the reagents and equipment used in this research were of analytical grade. Distilled-deionised water was used for reagents preparations. 


\subsection{Sample Collection}

Total of seven water samples were collected from surface and underground water bodies within the iron mining zone of Itakpe and its environment in Kogi State Nigeria. The sample locations are River Pompom (RPW), Estate borehole (EBW),Estate Stream (ESW), Osara Dam (ODW), Osara River (ORW),Eika-Adagu Well (EAW) and Eika-Turu Well (ETW). In each case, the water samples were collected following standard methods $[12,13]$.

The physical parameters analysed include $\mathrm{pH}$, electrical conductivity and total dissolved solids. The $\mathrm{pH}$ was determined using a digital $\mathrm{pH}$ meter, conductivity with a conductivity meter and total dissolved solids by gravimetric method. Total acidity, total alkalinity and total hardness were determined using titrimetric methods and chlorides by Mohr's method. Nitrate and sulphate were determined by colorimetric method. Heavy metals were determined using known standard methods[14,15].

Water samples were digested with the standard method proposed by the American Water Works Association [13]. $50 \mathrm{~cm}^{3}$ of each samples was treated with $5.0 \mathrm{~cm}^{3}$ of concentrated $\mathrm{HNO}_{3}$ and heated on a hot plate until it was evaporated to about $20.0 \mathrm{~cm}^{3}$. The digest was allowed to cool and another $5.0 \mathrm{~cm}^{3}$ of concentrated $\mathrm{HNO}_{3}$ was added, heating continue for one hour at $100^{\circ} \mathrm{C}$. It was then cool and then filtered. The filtrate was poured into a $50.0 \mathrm{~cm}^{3}$ standard volumetric flask and made up to the mark with distilled-deionised water. Portion of the solution was used for metal analysis with Atomic Absorption Spectrophotometer (AAS)APLHA 4 model.

\section{Results and Discussion.}

The results of the physicochemical analysis of both surface and underground water samples collected within the iron-ore mining zone of Kogi state and its environment are presented in Table 1.

The $\mathrm{pH}$ values of the water bodies ranged from 6.0-6.9 in dry season while rainy season ranged from 7.2-8.2. This indicates that the water is slightly acidic in the dry season and weakly alkaline in the rainy season. The low level of $\mathrm{pH}$ could be due to the presence of dissolve $\mathrm{CO}_{2}$. The $\mathrm{pH}$ values obtained in water samples fall within the recommended standard of 6.0-8.5 [17]. $\mathrm{pH}$ is an important parameter in water body since most of the aquatic organisms are adapted to an average $\mathrm{pH}$ and do not withstand abrupt changes. Generally, the $\mathrm{pH}$ of water is influence by geology of catchments area and buffering capacity of water.

The conductivity of water samples ranged from180.0-714.2 $\mu \mathrm{scm}^{-1}$ for the dry season and 181.0$718.2 \mathrm{\mu scm}^{-1}$ in rainy season with RPW having the highest value .Conductivity indicates the presence of dissolved solids and contaminants especially electrolytes. The values obtained in all the samples are below the maximum limit of $1000 \mu \mathrm{scm}^{-1}$ set by Standard Organisation of Nigeria [18]. The conductivity of most fresh water ranged from 10 to1000 $\mu \mathrm{scm}^{-1}$ but may exceed $1000 \mu \mathrm{scm}^{-1}$ especially in polluted waters or those receiving quantity of land run-off [19].

The results show that the presence of suspended and dissolved solids being higher in the rainy (42.0$124.0 \mathrm{mgL}^{-1}$ and $\left.75.3-207.8 \mathrm{mgL}^{-1}\right)$ than in the dry season $\left(40.0-121.0\right.$ and $\left.70.2-207.3 \mathrm{mgL}^{-1}\right)$ respectively. The total hardness levels of the samples varied between $38.4-73.5 \mathrm{mgL}^{-1}$ in the dry season and $38.50-76.40 \mathrm{mgL}^{-1}$ in the rainy season and is below the WHO standard of $300 \mathrm{mgL}^{-1}$ as $\mathrm{CaCO}_{3}$. It is mainly derived from weathering of minerals such as limestone $\left(\mathrm{CaCO}_{3}\right)$ or dolomite $\left(\mathrm{CaCO}_{3} \cdot \mathrm{MgCO}_{3}\right)$. Total hardness is the sum of $\mathrm{Ca}$ and $\mathrm{Mg}$ concentrations expressed as $\mathrm{CaCO}_{3}$ in $\mathrm{mgL}^{-1}$ [20]. Alkalinity and acidity ranged from $89.6-416.0 \mathrm{mgL}^{-1}, 8.1-$ $57.1 \mathrm{mgL}^{-1}$ in dry season and 90.6-417.1, 8.3-61.2 in the rainy season respectively. In natural water, alkalinity is caused by three major classes of minerals: hydroxides, carbonates and hydrogen carbonates. In all forms of effluents, alkalinity is due to the presence of salts of weak acid such as ethanoic, propanoic or the presence of ammonia hydroxides.

The concentrations of the chloride and sulphate are all within the WHO(1991) acceptable limits for the water, having values of $10.59-17.80,0.021-1.50 \mathrm{mgL}^{-1}$ in the dry season and $11.10-17.72,0.47-1.65 \mathrm{mgL}^{-1}$ in the rainy season. The concentration of nitrate in some of the samples are however slightly above limits of 45 $\mathrm{mLL}^{-1}$. These results agree with the earlier researchers in terms of prevalence of the parameters in the environments [21,22].

Table 1. Mean of the physicochemical parameters of the samples

\begin{tabular}{|c|c|c|c|c|c|c|c|c|c|c|}
\hline $\begin{array}{l}\text { Locatio } \\
n\end{array}$ & $\mathrm{pH}$ & $\begin{array}{l}\text { Conductivit } \\
\mathrm{y} \\
\left(\mu \mathrm{scm}^{-1}\right)\end{array}$ & $\begin{array}{l}\text { TSS } \\
\left(\mathrm{mgL}^{-}\right. \\
\left.{ }^{1}\right)\end{array}$ & $\begin{array}{l}\text { TDS } \\
\left(\mathrm{mgL}^{-1}\right)\end{array}$ & $\begin{array}{l}\mathrm{TH} \\
(\mathrm{mgL} \\
\left.{ }^{1}\right)\end{array}$ & $\begin{array}{l}\text { Alkalinit } \\
\text { y } \\
\left(\mathrm{mgL}^{-1}\right)\end{array}$ & $\begin{array}{l}\text { Acidity } \\
\left(\mathrm{mgL}^{-}\right. \\
\left.{ }^{1}\right)\end{array}$ & $\begin{array}{l}\text { Nitrate, } \\
\mathrm{NO}_{3}^{-} \\
\left(\mathrm{mgL}^{-}\right. \\
\left.{ }^{1}\right)\end{array}$ & $\begin{array}{l}\text { Chloride, } \\
\mathrm{Cl}^{-} \quad(\mathrm{mgL} \\
\left.{ }^{1}\right)\end{array}$ & $\begin{array}{l}\text { Sulphate, } \\
\mathrm{SO}_{4}^{-2}\left(\mathrm{mgL}^{-}\right. \\
\left.{ }^{1}\right)\end{array}$ \\
\hline RPW & $\begin{array}{l}7.40 \\
\pm 0.0 \\
1 \\
(6.10 \\
\pm 0.0 \\
1)\end{array}$ & $\begin{array}{l}716.18 \pm 0.04 \\
\text { (714.19 } 20.0 \\
\text { 2) }\end{array}$ & $\begin{array}{l}71.00 \\
\pm 0.10 \\
(65 \\
\pm 0.20)\end{array}$ & $\begin{array}{l}160.00 \\
\pm 0.80 \\
(150.00 \\
\pm 0.09)\end{array}$ & $\begin{array}{l}45.00 \\
\pm 0.31 \\
(45.11 \\
\pm 0.41)\end{array}$ & $\begin{array}{l}98.55 \pm 0 . \\
20 \\
(98.97 \pm \\
0.10)\end{array}$ & $\begin{array}{l}33.40 \\
\pm 0.40 \\
(30.50 \\
\pm 0.23)\end{array}$ & $\begin{array}{l}0.29 \\
\pm 0.01 \\
(0.28 \\
\pm 0.12)\end{array}$ & $\begin{array}{l}17.92 \pm 0.9 \\
2 \\
(17.80 \pm 0 . \\
32)\end{array}$ & $\begin{array}{l}1.65 \pm 0.60 \\
(1.50 \pm 0.42)\end{array}$ \\
\hline
\end{tabular}


Physico-chemical and mineral analysis of some Surface and underground waters from iron mining

\begin{tabular}{|c|c|c|c|c|c|c|c|c|c|c|}
\hline EBW & $\begin{array}{l}7.93 \\
\pm 0.0 \\
4 \\
(6.94 \\
\pm 0.0 \\
2)\end{array}$ & $\begin{array}{l}253.71 \pm 0.02 \\
(253.09 \pm 0.0 \\
3)\end{array}$ & $\begin{array}{l}60.00 \\
\pm 0.20 \\
(52.00 \\
\pm 0.10)\end{array}$ & $\begin{array}{l}195.00 \\
\pm 0.05 \\
(192.59 \\
\pm 0.72)\end{array}$ & $\begin{array}{l}38.50 \\
\pm 0.01 \\
(39.35 \\
\pm 0.00)\end{array}$ & $\begin{array}{l}103.60 \\
\pm 0.00 \\
(102.50 \\
\pm 0.90)\end{array}$ & $\begin{array}{l}61.20 \\
\pm 0.01 \\
(57.13 \\
\pm 0.12)\end{array}$ & $\begin{array}{l}18.00 \\
\pm 0.52 \\
(18.70 \\
\pm 0.40)\end{array}$ & $\begin{array}{l}14.52 \pm 0.5 \\
1 \\
(12.90 \pm 0 . \\
50)\end{array}$ & $\begin{array}{l}0.82 \pm 0.20 \\
(0.67 \pm 0.12)\end{array}$ \\
\hline ESW & $\begin{array}{l}7.90 \\
\pm 0.0 \\
5 \\
(6.00 \\
\pm 0.0 \\
3) \\
\end{array}$ & $\begin{array}{l}196.37 \pm 0.01 \\
(195.37 \pm 0.0 \\
3)\end{array}$ & $\begin{array}{l}124.0 \\
0 \\
\pm 0.11 \\
(121.0 \\
\pm 0.12)\end{array}$ & $\begin{array}{l}171.76 \\
\pm 0.04 \\
(171.74 \\
\pm 0.05)\end{array}$ & $\begin{array}{l}67.70 \\
\pm 0.60 \\
(60.74 \\
\pm 1.32)\end{array}$ & $\begin{array}{l}90.61 \pm 1 . \\
10 \\
(89.62 \\
\pm 0.01)\end{array}$ & $\begin{array}{l}8.30 \\
\pm 0.70 \\
(8.10 \\
\pm 0.42)\end{array}$ & $\begin{array}{l}24.03 \\
\pm 0.30 \\
(22.03 \\
\pm 0.36)\end{array}$ & $\begin{array}{l}18.50 \pm 0.4 \\
0 \\
(15.52 \pm 0 . \\
05)\end{array}$ & $\begin{array}{l}0.47 \pm 0.31 \\
(0.21 \pm 0.03)\end{array}$ \\
\hline ODW & $\begin{array}{l}7.72 \\
\pm 0.0 \\
4 \\
(6.20 \\
\pm 0.3 \\
5)\end{array}$ & $\begin{array}{l}181.00 \pm 0.00 \\
(180.00 \pm 0.0 \\
2)\end{array}$ & $\begin{array}{l}62.00 \\
\pm 0.03 \\
(62.00 \\
\pm 1.20)\end{array}$ & $\begin{array}{l}109.11 \\
\pm 0.30 \\
(107.10 \\
\pm 2.10)\end{array}$ & $\begin{array}{l}52.29 \\
\pm 0.42 \\
(50.29 \\
\pm 0.80)\end{array}$ & $\begin{array}{l}124.02 \pm . \\
01 \\
(125.00 \\
\pm 0.67)\end{array}$ & $\begin{array}{l}27.12 \\
\pm 0.60 \\
(24.64 \\
\pm 0.51)\end{array}$ & $\begin{array}{l}53.05 \\
\pm 0.40 \\
(51.06 \\
\pm 0.40)\end{array}$ & $\begin{array}{l}13.32 \pm 0.0 \\
7 \\
(11.20 \pm 0 . \\
03)\end{array}$ & $\begin{array}{l}0.98 \pm 0.21 \\
(0.98 \pm 0.40)\end{array}$ \\
\hline ORW & $\begin{array}{l}8.23 \\
\pm 0.0 \\
0 \\
(6.84 \\
\pm 0.0 \\
1) \\
\end{array}$ & $\begin{array}{l}341.00 \pm 0.05 \\
(341.00 \pm 0.0 \\
2)\end{array}$ & $\begin{array}{l}63.00 \\
\pm 0.04 \\
(60.00 \\
\pm 1.01)\end{array}$ & $\begin{array}{l}207.86 \\
\pm 0.8 \\
(207.30 \\
\pm 1.20)\end{array}$ & $\begin{array}{l}62.67 \\
\pm 0.01 \\
(61.67 \\
\pm 0.20)\end{array}$ & $\begin{array}{l}230.0 \\
\pm 0.55 \\
(210.56 \\
0.85)\end{array}$ & $\begin{array}{l}31.00 \\
\pm 1.12 \\
(30.00 \\
\pm 0.87)\end{array}$ & $\begin{array}{l}34.44 \\
\pm 0.12 \\
(30.56 \\
\pm 0.2)\end{array}$ & $\begin{array}{l}16.16 \pm 0.2 \\
4 \\
(14.56 \pm 0 . \\
70)\end{array}$ & $\begin{array}{l}0.95 \pm 0.44 \\
(0.82 \pm 0.42)\end{array}$ \\
\hline EAW & $\begin{array}{l}7.20 \\
\pm 0.0 \\
2 \\
(6.85 \\
\pm 0.0 \\
4)\end{array}$ & $\begin{array}{l}195.94 \pm 0.01 \\
(195.83 \pm 0.0 \\
3)\end{array}$ & $\begin{array}{l}46.12 \\
\pm .30 \\
(46.00 \\
\pm 0.30)\end{array}$ & $\begin{array}{l}153.70 \\
\pm 0.80 \\
(153.57 \\
\pm 0.40)\end{array}$ & $\begin{array}{l}39.91 \\
\pm 0.01 \\
(38.37 \\
\pm 0.20)\end{array}$ & $\begin{array}{l}417.11 \\
\pm 0.42 \\
(416.00 \\
\pm 0.85)\end{array}$ & $\begin{array}{l}29.82 \\
\pm 0.40 \\
(25.80 \\
\pm 0.41)\end{array}$ & $\begin{array}{l}39.41 \\
\pm 0.01 \\
(38.45 \\
\pm 0.30)\end{array}$ & $\begin{array}{l}11.42 \pm 0.3 \\
2 \\
(10.59 \pm 0 . \\
04)\end{array}$ & $\begin{array}{l}1.09 \pm 0.30 \\
(1.02 \pm 0.51)\end{array}$ \\
\hline ETW & $\begin{array}{l}7.69 \\
\pm 0.0 \\
2 \\
(6.20 \\
\pm 0.0 \\
2) \\
\end{array}$ & $\begin{array}{l}258.12 \pm 0.02 \\
(255.19 \pm 0.0 \\
3)\end{array}$ & $\begin{array}{l}44.00 \\
\pm 0.07 \\
(41.00 \\
\pm 0.62)\end{array}$ & $\begin{array}{l}75.32 \\
\pm 0.32 \\
(77.34 \\
\pm 0.81)\end{array}$ & $\begin{array}{l}45.10 \\
\pm 0.30 \\
(40.17 \\
\pm 0.45)\end{array}$ & $\begin{array}{l}364.00 \\
\pm 0.01 \\
(362.00 \\
\pm 0.04)\end{array}$ & $\begin{array}{l}32.00 \\
\pm 0.31 \\
(31.62 \\
\pm 0.40)\end{array}$ & $\begin{array}{l}18.30 \\
\pm 0.40 \\
(16.62 \\
\pm 0.42)\end{array}$ & $\begin{array}{l}14.30 \pm 0.5 \\
0 \\
(12.62 \pm 0 . \\
42)\end{array}$ & $\begin{array}{l}0.80 \pm 0.01 \\
(0.90 \pm 0.03)\end{array}$ \\
\hline
\end{tabular}

Values in the parenthesis $=$ dry season

TSS $=$ Total suspended solid TDS $=$ Total dissolved solid

$\mathrm{TH}=$ Total hardness

Table2. Concentration of metals in water samples $\left(\mathrm{mgL}^{-1}\right)$

\begin{tabular}{|l|l|l|l|l|l|l|l|l|}
\hline Location & $\mathrm{Pb}$ & \multicolumn{1}{c|}{$\mathrm{PI}$} & $\mathrm{Cd}$ & $\mathrm{Cr}$ & $\mathrm{PI}$ & $\mathrm{Fe}$ & \multicolumn{2}{c|}{ PI } \\
\hline RPW & $1.92 \pm 0.02$ & 192 & $0.73 \pm 0.01$ & 73 & $2.00 \pm 0.01$ & 40 & $20.00 \pm 0.01$ & 66.7 \\
& $(2.10 \pm 0.04)$ & $(210)$ & $(0.71 \pm 0.04)$ & $(71)$ & $(1.89 \pm 0.08)$ & $(37.8)$ & $(16.14 \pm 0.01)$ & $(53.8)$ \\
\hline EBW & $0.10 \pm 0.01$ & 10 & $0.01 \pm 0.03$ & 1 & $0.83 \pm 0.05$ & 16.6 & $16.14 \pm 0.02$ & 53.8 \\
& $(0.08 \pm 0.03)$ & $(8)$ & $(0.01 \pm 0.02)$ & $(1)$ & $(0.80 \pm 0.03)$ & $(16)$ & $(10.00 \pm 0.04)$ & $(33.3)$ \\
\hline ESW & $0.01 \pm 0.00$ & 1 & $0.03 \pm 0.44$ & 3 & $0.01 \pm 0.04$ & 0.24 & $8.11 \pm 0.03$ & 27 \\
& $(0.02 \pm 0.05)$ & $(2)$ & $(0.02 \pm 0.41)$ & $(2)$ & $(0.01 \pm 0.02)$ & $(0.2)$ & $(7.00 \pm 0.05)$ & $(23.3)$ \\
\hline ODW & $0.14 \pm 0.06$ & 14 & $0.37 \pm 0.01$ & 37 & $0.72 \pm 0.00$ & 14.4 & $6.66 \pm 0.04$ & 22.2 \\
& $(0.32 \pm 0.03)$ & $(32)$ & $(0.26 \pm 0.04)$ & $(26)$ & $(0.55 \pm 0.01)$ & $(11)$ & $(6.61 \pm 0.05)$ & $(22.0)$ \\
\hline ORW & $0.12 \pm 0.04$ & 12 & $0.03 \pm 0.01$ & 3 & $1.00 \pm 0.12$ & 20 & $5.22 \pm 0.02$ & 17.4 \\
& $(0.10 \pm 0.02)$ & $(10)$ & $(0.04 \pm 0.02)$ & $(4)$ & $(0.96 \pm 0.04)$ & $(19.2)$ & $(3.00 \pm 0.03)$ & $(10)$ \\
\hline EAW & $1.12 \pm 0.03$ & 22.4 & $0.02 \pm 0.03$ & 1.7 & $0.72 \pm 0.05$ & 14.4 & $6.23 \pm 0.05$ & 20.77 \\
& $(1.26 \pm 0.01)$ & $(25.2)$ & $(0.02 \pm 0.01)$ & $(1.5)$ & $(0.64 \pm 0.01)$ & $(12.8)$ & $(5.26 \pm 0.02)$ & $(17.5)$ \\
\hline ETW & $0.20 \pm 0.01$ & 20 & $0.13 \pm 0.01$ & 13 & $0.93 \pm 0.02$ & 18.6 & $7.70 \pm 0.04$ & 25.7 \\
& $(0.17 \pm 0.02)$ & $(17)$ & $(0.10 \pm 0.04)$ & $(10)$ & $(0.85 \pm 0.04)$ & $(17)$ & $(5.76 \pm 0.04)$ & $(19.2)$ \\
\hline
\end{tabular}

Values in the parenthesis $=$ dry season

The results of the analyses of lead $(\mathrm{Pb})$, cadmium $(\mathrm{Cd})$, chromium $(\mathrm{Cr})$ and iron $(\mathrm{Fe})$ in different water samples in the studied area are summarized in Table 2. It is evident from the table that the concentrations of the metals in most of water samples exceeded the WHO(1991) guide limits at a level that puts the health of the unsuspecting public at risk. The Pollution Index (PI) showed that metal levels in both surface and ground water samples pose serious threat to health since PI calculated as a ratio of experimental value to the tolerance limit were greater than one (PI>1) in most of sampled areas.

The concentration of $\mathrm{Pb}$ ranges from $0.01-1.9 \mathrm{mgL}^{-1}$ in the raining season and $0.1-2.1 \mathrm{mgL}^{-1}$ in the dry season. RPW has the highest value and ESW has the least value of $\mathrm{Pb}$. Lead has been found to be responsible for quite a number of ailments in humans such as chronic neurological disorder especially in foetuses and children [23]. The maximum permissible limits for Cd set at $0.005 \mathrm{mgL}^{-1}$ [24], $0.003 \mathrm{mgL}^{-1}$ [18], 
$0.01 \mathrm{mgL}^{-1}$ [26] were all found to be lower than values obtained from all the samples as indicated in Table 2. The concentration of $\mathrm{Cd}$ in the water samples ranges from $0.01-0.73 \mathrm{mgL}^{-1}$ in the rainy season and $0.01-0.71$ $\mathrm{mgL}^{-1}$ in the dry season. RPW also has the most elevated value of $0.7 \mathrm{mgL}^{-1}$ and $0.7 \mathrm{mgL}^{-1}$ while EBW has the least values of $0.01 \mathrm{mgL}^{-1}$ for the two seasons. Cadmium is one of the most toxic elements with reported carcinogenic effects in humans[27]. It accumulates mainly in the kidney and liver and high concentrations have been found to lead to chronic kidney dysfunction. The concentration of chromium ranges from $0.01-2.0 \mathrm{mgL}^{-1}$ in the rainy season and $0.01-1.89 \mathrm{mgL}^{-1}$ in the dry season. It has PI of 40 and 37 for raining and dry seasons in the sample RPW and PI of 0.24 and 0.2 for the sample ESW. This implies that RPW is highly polluted with respect to chromium and other metals discussed. The concentration of $\mathrm{Fe}$ in the samples for both seasons ranged from 5.2-20.0 mgL $\mathrm{mg}^{-1}$ and 3.0-16.1 mgL $\mathrm{m}^{-1}$. Higher concentration of iron is expected because it is the most abundant metal in the area [28]. High concentration of iron could results in effect like unpleasant taste and odour of water. The PI values in the Table 2 show the extent of metal pollution of the water bodies. The relative abundance of $\mathrm{Pb}, \mathrm{Cd}, \mathrm{Cr}$ and $\mathrm{Fe}$ in water samples within the area could have been influenced by human activities such as quarry operations, mining of iron-ore, flooding, poor waste disposal and sanitation. This further confirmed by their PI being greater than unity.

\section{Conclusion}

There is an increased level of $\mathrm{Pb}, \mathrm{Cr}$, $\mathrm{Cd}$ and $\mathrm{Fe}$ in the order: $\mathrm{Pb}<\mathrm{Cd}<\mathrm{Cr}<\mathrm{Fe}$. From the results obtained water in the area are polluted with these metals as their concentration were found to be above WHO recommended limits. Regular monitoring of heavy metal levels in the soil and water should be ensured to reduced the risk of heavy metal poisoning in the area.

\section{References}

[1] G. U. Chukwu,Water quality assessment of Boreholes in Umuahia North Local Government area of Abia state ,Nigeria,Pacific Journal of Science and Tecnology 9 (2),2008, 590-596

[2] Adekunle A.S, Effects of industrial effluents on quality of well water within Asa Dam industrial Estate,Ilorin, Nigeria. Nature and Science 7(1), 2009

[3] Altman S.J and Parizek R.R ,Dilution of nonpoint source nitrate in ground water, J.Environ quality,24, 1995,707-717.

[4] Lowe D.J ,The Economic Environmental management, $2^{\text {nd }}$ Edition (Camelot Press,Britain, 1978)

[5] Ayodele J. T and Ahmed A ,Monitoring air pollution in Kano municipality by chemical analysis of Scots Spine Needle (Pinus Sylvestric L.) for sulphur, Environmentalist 21,2001, 81-86

[6] Ademoroti CMA, Standard methods for water and effluent Analysis, ( Foludex Press LTD, Ibadan ,1996)

[7] American Public Health Association (APHA), Standard methods for examination of water and waste water, $18^{\text {th }}$ edition.

[8] Stirling H.P, Chemical and Biological methods for water Analysis for Aquaculturists, ( $1^{\text {st }}$ edition) Instituteof Agriculture,university of Stirling, Stirling,Britain, $1985,118-119$

[9] Radojevic M and Bashkin V.N ,Practical Environmental Analysis “ Cambridge U.K, Royal Society of Chemist, 1999,189-204

[10] Adefemi S.O and Awokunmi E.E ,Determination of physicochemical parameters and heavy metals in water samples from Itaogbolu area of Ondo-State Nigeria. African journal of environmental Science and Technology 4 (3), 2010, 145-148.

[11] Adekola F. A and Eletta O.A .A, A study of heavy metal pollution of Asa River,Ilorin.Nigeria; trace metal monitoring and geochemistry. Environ Monit Asses 125,2007,157-163

[12] American Society for Testing and Material Standard methods for acidity and alkalinity of water, 1982

[13] American Water Works Association (AWWA) ,Standard Methods for the examination of water and wastewater, $16^{\text {th }}$ edition ,1985

[14] Hunt D.T and Wilson A.L ,The chemical analysis of water, General principles ,1986

[15] AOAC (1990): Official Methods of Analysis. Association of Analytical Chemist (14 ${ }^{\text {th }}$ edition). Arlington, Virginia.

[17] World Health Organization (WHO),International Standards for drinking water, Geneva, 1991

[18] Standard Organization of Nigeria,Specification for portable water, plot 1687, Lame street, Wuse, 2003

[19] Mathias R.S ,Principle of water quality, $4^{\text {th }}$ edition. Fergamon Press, Oxford London, 1992

[21] Olajire A.A and Imeokparie F.E ,A study of the water quality of the Osun river; metal monitoring and geochemistry. Bull. Chem. Ethiop. 14 (1)1-8, 2000

[22] Edema M .O,Omemu A.M, Fapetu O.M ,Microbiology and physicochemical Analysis of different sources of drinking water in Abeokuta, Nigeria,Nig J Microbiol 15 (1) 57-62, 2001

[23] Mohan B.S and Hosetti B.B ,Lead toxicity to Salvinia natans grown in macrophyte ponds ,J. Ecotoxical Environ. Monit, 18 ,3-7 , 1998

[24] World Health Organization (WHO), Guideline for drinking water quality, WHO, Geneva, 2004

[26] U.S Env protection Agency (USEPA) : Interim Guidance on interpretation and implementation of Aquatic Life Criteria for metals, USEPA Health and Ecological Criteria Division, Office of Science and Technology.

[27] Goering P. L, Waakes M.P and Klaassen C.D, In Goyer R.A and Cherian M.G (Eds), Handbook of Experimental Pharmcology vol. 115 Springer, New York, 189, 1994

[28] Obasi C.K Mineralogical characteristic and Genetic significance of Hematite in Itakpe Iron ore deposit, J of mining and geology 34 (2) $, 1149-1562,1998$ 